\title{
PENDAMPINGAN UJI KADAR AIR KUALITAS VCO BERDASARKAN STANDAR NASIONAL INDONESIA PRODUKSI KWT TUNAS AMERTA
}

\author{
Dewi Oktofa Rachmawati ${ }^{1}$, Iwan Suswandi ${ }^{2}$, L. P. Budi Yasmini ${ }^{3}$ \\ 1,2,3 Jurusan Fisika dan Pengajaran IPA FMIPA, Universitas Pendidikan Ganesha \\ email: dewioktofa.r@undiksha.ac.id, iwan.suswandi@undiksha.ac.id, \\ budi.yasmini@undiksha.ac.id
}

\begin{abstract}
Abstrak
Daya simpan VCO produk KWT Tunas Amerta sekitar 6-7 bulan. Produksi VCO dilakukan dalam jumlah masih terbatas dan bersifat tidak kontinu. Kesulitan melakukan uji kadar air berdasarkan standar mutu yang ditetapkan Standar Nasional Indonesia (SNI) membuat kontrol kualitas tidak dapat dilakukan secara berkala. Solusi permasalahan ini dituangkan dalam bentuk pendampingan uji kadar air kualitas VCO berdasarkan SNI. Tujuan pendampingan ini adalah membekali peserta pengabdian melakukan uji kadar air sesuai standar mutu VCO berdasarkan SNI :7381-2008. Kegiatan P2M diikuti oleh 5anggota KWT VCO Tunas AmertaDesa Panji Anom. Evaluasi kegiatan menitikberatkan pada proses pengujian kadar air sesuai prosedur. Keberhasilan menentukan nilai kadar air VCO digunakan sebagai kriteria ketercapaian kegiatan pengabdian ini. Hasil pelaksanaan pendampingan uji kadar air kualitas VCO menunjukkan bahwa peserta berhasil menentukan nilai kadar air dalam VCO yang diproduksi. Hasil uji kadar air dalam VCO Lengis Dhee mencapai 0,09\%. Nilai ini lebih kecil dari nilai yang dipersyaratkan dalam standar mutu VCO, yaitu maksimum $0,2 \%$.
\end{abstract}

Kata-kata kunci: VCO, kadar air, Standar Nasional Indonesia (SNI)

\begin{abstract}
The shelf life of VCO from Tunas Amerta KWT products is about 6-7 months. VCO production is carried out in limited quantities and is not continuous. The difficulty of conducting a water content test based on the quality standards set by the Indonesian National Standard (SNI) makes it impossible to carry out regular quality control. The solution to this problem is stated in the form of assistance in testing the water content of VCO quality based on SNI.The purpose of this assistance was to equip service participants to test the water content according to the VCO quality standard based on SNI:7381-2008. The P2M activity was attended by 5 members of KWT VCO Tunas AmertaPanjiAnom Village. Evaluation of activities focused on the process of testing the water content according to the procedure.The success of determining the value of the water content of VCO was used as a criterion for the achievement of this service activity.The results of the mentoring implementation of the VCO quality water content test showed that the participants succeeded in determining the value of the water content in the VCO produced. The results of the water content test in the VCO LengisDhee reached $0.09 \%$. This value is smaller than the value required in the VCO quality standard, that is $0.2 \%$ max.
\end{abstract}

Keywords: VCO, moisture content, Indonesian National Standard (SNI) 


\section{PENDAHULUAN}

Desa Panji Anom termasuk salah satu desa yang terletak pada daerah aliran sungai Banyumala. Desa ini diapit oleh desa Pemaron yang terletak disebelah utara, desa Wanagiri disebelah selatan, desa Panji di sebelah timur, dan desa Tegalinggah disebelah barat. Luas desa Panji Anom sekitar 975.850 ha meliputi pemukiman, persawahan, perkebunan, kuburan, pekarangan, perkantoran, dan sarana umum lainnya. Desa Panji Anom terdiri dari 4 dusun, salah satunya adalah dusun Abasan. Dusun Abasan merupakan salah satu dusun yang menghasilkan buah kelapa yang berlimpah. Di atas tanah perkebunan seluas $10 \mathrm{ha}, 1.000 \mathrm{kw}$ buah kelapa dapat dipanennya. Namun, buah kelapa ini belum dimanfaatkan secara maksimal. Pemanfaatannya terbatas untuk pemenuhan kebutuhan rumah tangga. Buah kelapa dijual di pasar-pasar tradisional di luar dusun Abasan.

Kemudahan proses pembuatan VCO, biaya produksi yang ekonomis, dan tidak diperlukan penambahan bahan kimia tambahan menggerakkan anggota KWT Tunas Amerta dusun Abasan ini mengembangkan usaha indutri rumahan (home industry) berupa Virgin Coconut Oil atau yang dikenal dengan sebutan VCO. Dalam proses produksinya, kelompok ini menerapkan teknik pengadukan. Teknik ini dipilih karena lebih sederhana dan mudah dilakukan, tidak membutuhkan teknologi tinggi dan peralatan modern. 600 mI VCO dihasilkan dari 20 buah kelapa tua yang telah diparut dan ditambahkan air. Proses menghasilkan santan dilakukan secara tradisonal, yaitu memeras menggunakan bantuan kain. VCO dihasikan setelah melalui proses pemisahan dari blondo dan air. Selanjutnya, dilakukan penyaringan melalui 4 tahap.Tahapan tersebut adalah pertama, penyaringan dengan menggunakan saringan. Minyak dipisahkan dari blondo-blondo yang ikut dalam proses pemisahan VCO. Kedua, penggunaan batu zeolit. Zeolit merupakan mineral yang terdiri dari kristal alumino silikat terhidrasi yang mengandung kation alkali atau alkali tanah dalam kerangka tiga dimensinya. lon-ion logam tersebut dapat diganti oleh kation lain tanpa merusak struktur zeolit dan dapat menyerap air secara reversibel (Bekkum dkk.,1981). Ketiga, penyaringan oleh kapas dan terakhir menggunakan kertas saring. Selanjutnya, VCO ditempatkan dalam wadah hiegenis. Secara fisik, VCO yang dihasilkan jernih, tidak berwarna, beraroma minyak kelapa, tidak tengik, dan memiliki rasa minyak kelapa. Hasil yang sama juga ditunjukkan pada penelitian Asy'ary, M. (2006:4)

Virgin Coconut Oil (VCO) atau minyak kelapa murni merupakan minyak hasil olahan buah kelapa tua tanpa melalui proses pemanasan.Komponen utama VCO adalah asam lemak jenuh sekitar 90\% dan asam lemak tak jenuh sekitar $10 \%$. Asam lemak jenuh VCO didominasi oleh asam laurat.VCO mengandung \pm $53 \%$ asam laurat dan sekitar 7\% asam kaprilat. Keduanya merupakan asam lemak rantai sedang yang disebut Medium Chain Fatty Acid (MCFA). Penelitian Marina, A.M (2009: 112) menunjukkan bahwa VCO dengan kandungan asam laurat berfungsi sebagai antioksidan aktif. Menurut Hee, Y.Y(2017:119), kandungan antioksidan dan asam lemak rantai menengah pada VCO memiliki kemampuan untuk meningkatkan efek kesehatan. VCO terbukti mampu menanggulangi banyak penyakit seperti jantung, asam urat, diabetes, paru-paru, dan hipertensi. VCO baik untuk memperhalus kulit, memperlancar proses kelahiran pada ibu hamil, dan menambah ASI pada ibu menyusui.

VCO yang dihasilkan melalui proses tanpa pemanasan, penyulingan, pemutihan, dan pengharuman tidak mengubah nutisi yang dikandung minyak. Proses produksi yang menerapkan penggunaan panas dapat menurunkan kadar a-tokoferol dan polifenol sekitar $25 \%$. Bahkan dapat hilang sama sekali dengan pemanasan yang berlebihan (Dayrit, 2000: 2). VCO memiliki sejumlah sifat fisik yang menguntungkan, di antaranya memiliki kestabilan secara kimia, bisa disimpan dalam jangka panjang dan tidak cepat tengik, serta tahan terhadap panas. Perbedaan teknik pembuatan VCO, utamanya dalam hal pemisahan minyak dari protein kelapa 
akan menghasilkan kualitas VCO yang berbeda.

Secara fisik, VCO harus berwarna jernih yang menandakan bahwa di dalamnya tidak tercampur oleh bahan dan kotoran lain. Apabila di dalam VCO masih terdapat kandungan air,akan ada gumpalan berwarna putih. Gumpalan tersebut merupakan komponen blondo dari protein yang tidak tersaring semuanya. Tercampurnya komponen seperti ini secara langsung akan berpengaruh terhadap kualitas VCO. VCO dengan kualitas baik memiliki aroma minyak kelapa, jernih tidak berwarna, dan memiliki rasa khas minyak kelapa.

Bau tengik terjadi karena proses oksidasi yang disebabkan tingginya kadar air dalam VCO. Kadar air yang terdapat dalam VCO dapat mempengaruhi mutu/kualitas VCO yang dihasilkan. Air mempercepat terjadinya proses hidrolisa pada minyak. Swern (dalam Sardi.H. D., 2017:437) menyatakan bahwa semakin tinggi kandungan air pada minyak, semakin besar kemungkinan minyak tersebut terhidrolisis menjadi gliserol dan asam lemak bebas. Kadar air yang tinggi mempercepat kerusakan VCO, sebaliknya kadar air rendah VCO bersifat tahan lama. Selain kadar air yang tinggi, protein yang masih tersisa dari proses penyaringan juga dapat mempercepat ketengikan VCO bila melebihi ambang batas $0,2 \%$ (SNI 3781, 2008:1). Daya simpan VCO berkualitas dapat mencapai $\geq 12$ bulan.Kualitas VCO yang menurun atau rusak tidak dapat memberi manfaat atau bahkan bisa menimbulkan penyakit lainnya

SNI merupakan standar yang berlaku secara nasional di wilayah Indonesia.Standar ini ditetapkan oleh pemerintah untuk diterapkan pada berbagai hasil produksi yang dibuat oleh masyarakat, baik produksi perorangan maupun organisasi atau perusahaan. Berdasarkan SNI VCO, syarat mutu, cara uji, pengambilan contoh, higiene dan minyak VCO ditetapkan sebagai standar mutu. Syarat mutu kadar air dalam VCO berdasarkan SNI: 7381-2008, 0.2\%. Kadar air yang melebihi $0.2 \%$ dapat menurunkan kualitas minyak. VCO dengan kualitas baik ditandai dengan daya simpan melebihi 12 bulan, tidak mengubah warna, aroma, rasa dan nutrisi yang terkandung didalamnya.

VCO produksi KWT Tunas Amerta memiliki daya simpan 6-7 bulan, akibatnya diproduksi dalam jumlah terbatas dan bersifat tidak kontinu. Kesulitan melakukan uji kadar air dalam VCO oleh anggota KWT VCO Tunas Amerta mengakibatkan tidak adanya kontrol kualitas secara berkala. Belum terujinya kadar air membuat produk VCO KWT Tunas Amerta belum berani dipasarkan secara luas diluar wilayah desa Panji Anom. Oleh karenanya, perlu dilakukan pendampingan dalam melakukan uji kadar air kualitas VCO. Hasil uji ini dapat digunakan sebagai bahan refleksi untuk peningkatan kualitas produk dan kontrol kualitas. Pendampingan uji kadar air kualitas VCO dipandang sangat urgen/penting untuk meningkatkan per-ekonomian masyarakat dusun Abasan melalui produksi VCO berkualitas.

Kegiatan pengabdian kepada masyarakat ini bertujuan memberi pendampingan melakukan uji kualitas kadar air VCO.

\section{METODE}

Kegiatan pengabdian kepada masyarakat ini melibatkan 5 anggota KWT VCO Tunas Amerta. Metode pelaksanaannya adalah pendampingan cara melakukan uji kualitas kadar air. Metode ini dipilih untuk mengatasi masalah kualitas produksi VCO. Faktor penyebab munculnya masalah tersebut adalah kesulitan melakukan uji kualitas kadar air berdasarkan standar mutu yang ditetapkan Standar Nasional Indonesia (SNI)..

Prosedur kerja pengabdian ini berupa pendampingan pada peserta pengabdian dalam melakukan prosedur uji kadar air berdasarkan SNI dengan metode oven dan menentukan persentasi kadar air. Kehilangan pada bobot pemanasan $105^{\circ} \mathrm{C}$ dianggap sebagai kadar air dalam VCO. Peralatan yang digunakan pada uji ini adalah neraca analitik terkalibrasi 
dengan ketelitian 0,01 gram, oven listrik $103^{\circ} \mathrm{C} \pm 2^{\circ} \mathrm{C}$, botol timbang diameter 50 $\mathrm{mm}$, tinggi $30 \mathrm{~mm}$,atau kruss porselin dasar rata dan desikator. Uji kualitas kadar air dilakukan dengan langkah: 1) panaskan botol berisi pasir laut kering dan pengaduk dalam oven listrik dengan suhu $105^{\circ} \mathrm{C}$ selama $\left.1 \mathrm{jam}, 2\right)$ dinginkan dalam desikator selama $1 / 2$ jam, 3) timbang dan catat bobotnya, 4) timbang minyak dalam botol, timbang bobotnya, 5) panaskan dalam oven listrik pada suhu $105^{\circ} \mathrm{C}$ selama 1 jam, 6) dinginkan dalam desikator selama $1 / 2$ jam, 7) Timbang bobot botol yang berisi cuplikan minyak, dan 8 ) ulangi pemanasan dan penimbangan sampai diperoleh bobot tetap.

Kadar air dinyatakan dalam persen (\%) dan dihitung menggunakan rumus :

dengan:

$$
K A=\frac{m_{1}-m_{2}}{m_{1}} \times 100 \%
$$

$m_{1}$ adalah bobot cuplikan

$m_{2}$ adalah bobot cuplikan setelah pengeringan

Evaluasi kegiatan menitikberatkan pada proses melakukan pengujian kadar air sesuai prosedur standar mutu yang ditetapkan SNI. Evaluasi dilakukan dengan teknik observasi dengan menggunakan pedoman observasi. Indikator yang digunakan sebagai kriteria ketercapaian tujuan kegiatan adalah keberhasilan menentukan nilai kadar air dalam produk VCO yang dihasilkannya.

\section{HASIL DAN PEMBAHASAN}

Kelompok Wanita Tani (KWT) Tunas Amerta dusun Abasan Desa Panji Anom telah berhasil memproduksi VCO yang diberi label VCO Lengis Dhee.VCO merupakan produk home industry dari warga Dusun Abasan, yang telah dikembangkan kurang lebih 10 tahun lalu. Pemasaran masih terbatas untuk kebutuhan masyarakat di dusun Abasan. Penyimpanan VCO dalam jangka panjang melebihi 7 bulan membuat VCO mengalami penurunan kualitas (rusak). Hal ini ditandai dengan perubahan bau VCO menjadi tengik.
Pendampingan melakukan cara uji kadar air dalam VCO diikuti oleh 5 anggota KWT VCO Tunas Amerta Dusun Abasan Desa Panji Anom. Peserta pelatihan sangat antusias mengikuti pendampingan ini karena dapat melakukan pengukuran secara mandiri untuk mengetahui kualitas produk dan dapat melakukan kontrol kualitas produk.

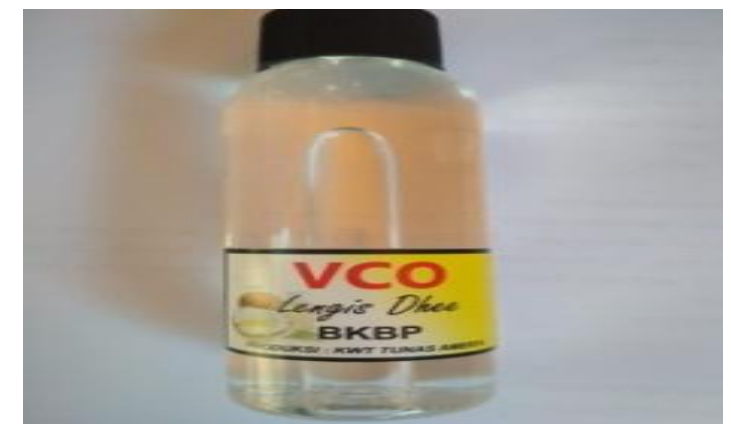

Gambar 1. Produk VCO Tunas Amerta

Sebelum dilakukan pendampingan cara uji kualitas kadar air, disampaikan wawasan tentang standar kualitas VCO, prasyarat kadar air yang diperkenankan, pengaruh kadar air terhadap kualitas VCO, dan prosedur cara uji kadar air berdasarkan SNI: 7381-2008. Materi cara atau langkah kerja uji kadar air dapat digunakan sebagai panduan melakukan uji kadar air atau kontrol kadar air.

Pendampingan ini telah mengubah pandangan peserta bahwa kadar air adalah parameter yang harus dikontrol untuk menjaga kualitas VCO. Selain itu, pendampingan telah menumbuhkan rasa optimis dalam masalah daya simpan, sehingga kualitas akan dapat diatasi.

Gambar 1 menunjukkan peralatan yang digunakan pada uji parameter kadar air. Pipet digunakan untuk memindahkan cairan dari satu wadah ke wadah lain. Kruss porselen sebagai wadah unyuk menempatkan bahan berupa cairan yang akan dibakar dalam oven pada suhu tinggi $\left(105^{\circ} \mathrm{C}\right)$. Oven listrik digunakan untuk pemanasan dan neraca analitik dengan tingkat ketelitian 0,0001 gram. Neraca analitik digunakan untuk mengukur massa VCO. Desikator digunakan untuk mengeringkan.Pada alat ini terdapat gel silika yang berfungsi sebagai zat penguap berbentuk butiran bulat berwarna biru. 
Gelas ukur digunakan mengukur volume cairan.
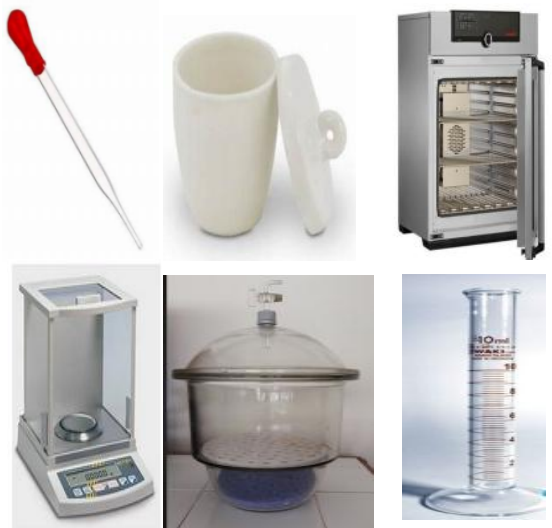

Gambar 2.Peralatan uji kadar air

Semua peserta dapat melakukan prosedur uji kadar air sesuai standar mutu VCO.

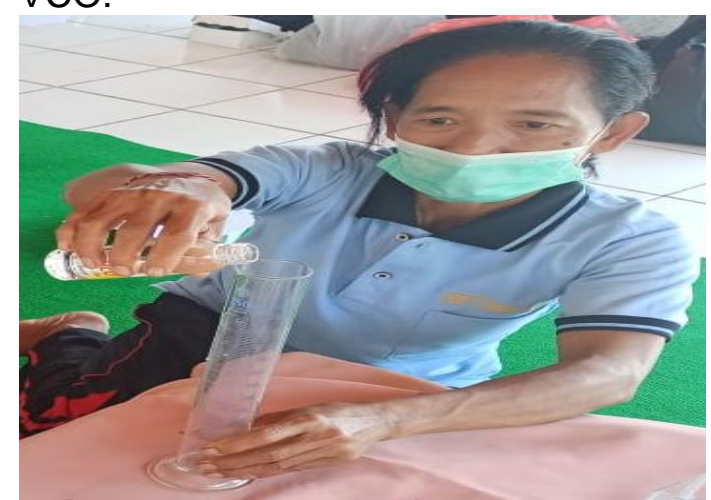

Gambar 3. Pendampingan uji kadar air
Pengulangan pemanasan dan pendinginan/pengeringan dalam desikator dilakukan sebanyak 3 kali hingga mencapai massa konstan.

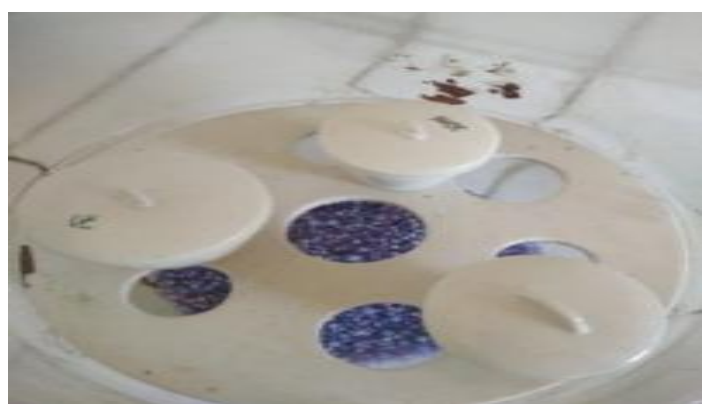

Gambar 4. Pengeringan pada desikator

Hasil evaluasi menunjukkan peserta pelatihan dapat melakukan uji kadar air kualitas VCO sesuai dengan standar mutu yang ditetapkan. Data massa VCO sebelum dan sesudah pengeringan yang diperoleh disajikan pada tabel 1.

Tabel 1. Data massa sebelumdan setelah pemanasan

\begin{tabular}{crrrrrr}
\hline Sampel Uji & \multicolumn{2}{c}{ Massa (gram) } & \multicolumn{4}{c}{ Massa pada Pengulangan Pemanasan (gram) } \\
& Sebelum & Pemanasan & 1 kali & 2 kali & 3 kali & 4 kali \\
\hline 1 & 8.5412 & 8.5333 & 8.5339 & 8.5333 & 8.5333 & 8.5333 \\
2 & 9.0896 & 9.0818 & 9.0823 & 9.0814 & 9.0808 & 9.0808 \\
3 & 8.1160 & 8.1151 & 8.1100 & 8.1093 & 8.1086 & 8.1086 \\
Rata-rata & 8.5823 & 8.5767 & 8.5754 & 8.5747 & 8.5742 & 8.5742 \\
SD & 0.4881 & 0.4875 & 0.4848 & 0.4874 & 0.4874 & 0.4874 \\
\hline
\end{tabular}

Berdasarkan data pada tabel 2 dan persamaan (1), nilai kadar air dalam VCO
Lengis Dhee dapat ditentukan. Hasilnya disajikan pada tabel 2. 
Tabel 2. Nilai kadar air dalam VCO Lengis Dhee

\begin{tabular}{|c|c|c|c|c|}
\hline $\begin{array}{c}\text { Sampel } \\
\text { Uji }\end{array}$ & $\begin{array}{l}\text { Massa sebelum } \\
\text { pemanasan (gr) }\end{array}$ & $\begin{array}{l}\text { Massa setelah } \\
\text { pemanasan (gr) }\end{array}$ & $\begin{array}{c}\text { Selisih } \\
\text { Massa (gr) }\end{array}$ & Kadar Air (\%) \\
\hline 1 & 8.5412 & 8.5333 & 0.0079 & 0.09 \\
\hline 2 & 9.0896 & 9.0808 & 0.0088 & 0.10 \\
\hline 3 & 8.1160 & 8.1086 & 0.0074 & 0.09 \\
\hline Rata-rata & 8.5823 & 8.5742 & 0.0080 & 0.09 \\
\hline SD & 0.4881 & 0.4874 & 0.0007 & 0.003 \\
\hline \multicolumn{4}{|c|}{ Kadar Air VCO Lengis Dhee } & $0.09 \pm 5.32 \mathrm{E}-03$ \\
\hline
\end{tabular}

Berdasarkan hasil uji kadar air pada kegiatan pendampingan, VCO Lengis Dhee mengandung kadar air sejumlah $0.09 \pm 5.32 E-03 \%$. Nilai ini lebih kecil dari prasyarat nilai standar mutu VCO berdasarkan SNI: 3781-2008, yaitu 0,2\%. Kadar air dalam VCO dipengaruhi jenis kelapa yang digunakan pada proses pembuatan VCO (Sardi Hi. D, 2013:437). Penelitian oleh Oseni, N. T. (2017:64) menunjukkan bahwa kadar air dalam VCO yang diproduksi dengan metode sentifugasi mencapai 0,34\%. Kadar air dalam VCO yang diproduksi dengan cara fermentasi mencapai 0,1463\% (Arisanti, D, 2020: 23). Penelitian Asiah, N (2019:4) menunjukkan teknik fermentasi campurankultur dalam pembuatan VCO menghasilkan kadar air bervariasi dari 0,020\%-0,035\%.

Kadar air adalah jumlah (dalam \%) air yang menguap pada pemanasan dengan suhu dan waktu tertentu. Jika dalam minyak terdapat air, maka akan mengakibatkan reaksi hidrolisis yang menyebabkan kerusakan minyak. Reaksi hidrolisis akan menyebabkan ketengikan pada minyak (Ketaren, S.,1986:173).

Penggunaan batu zeolit dalam proses penyaringan minyak kelapa murni yang dilakukan oleh anggota KWT VCO Tunas Amerta menghasilkan kadar air dalam minyak kurang dari prasyarat maksimum, yaitu $0,2 \%$. Penelitian oleh Nurani, I (2016:372) menunjukkan penggunaan batu zeolit dapat menurunkan kadar air pada pemurnian minyak.

Penggunaan peralatan digital memudahkan bagi peserta dalam mendapatkan nilai terukur dengan ketelitian yang tinggi. Kurang telitinya peserta dalam perhitungan mengakibatkan kesalahan menentukan nilai kadar air. Peralatan oven listrik dengan pengatur suhu dan waktu secara otomatis dan neraca analitik digital belum dimiliki anggota KWT Tunas Amerta. Penggunaan oven tradisonal dan neraca digital dapat digunakan, namun tidak sesuai dengan standar mutu cara uji kadar air. Pendampingan uji kadar air kualitas VCO telah mampu membekali anggota KWT VCO Tunas Amerta melakukan uji kadar air. Produsen VCO Tunas Amerta dapat melakukan uji kadar air secara mandiri untuk mengontrol kualitas atau meningkatkan kualitas.

\section{KESIMPULAN}

Simpulan

kegiatan pengdampingan ini adalah peserta dapat melakukan uji kadar kualitas VCO sesuai dengan cara uji menurut SNI: 3781-2008. Kualitas VCO dipengaruhi banyak factor, antara lain bahan baku yaitu kelapa, metode dan perlakuannya sehingga setiap perubahan yang dilakukan akan mengubah nilai kadar air dalam VCO. Oleh karena itu, disarankan untuk melakukan pengujian kadar air secara berkala untuk mengontrol kualitas produk. Selain itu, perlu dilakukan uji cemaran mikroba, logam, arsen, asam lemak bebas, dan kandungan asam lemak hasil dari penjernihan dengan batu zeolit.

\section{DAFTAR PUSTAKA}

Arisanti, D., Angelia, I.O. 2020.Peningkatan Kualitas Minyak Kelapa Murni (VC)) Terfermentasi Kultur Kering Bakteri Asam Laktat (BAL) terhadap Rendemen dan Kadar Air.Jurnal Pertanian, 11(1) 21-24.

Asiah, N. Astuti, R.M.Cempaka, L, and Setiani R.2019. Physical and Chemical Characteristic of Virgin Coconut Oil under Mix Culture Fermentation Technique.Journal of Physics: Engineering, Education, 
Applied Sciences, and Technology. 364 (2019) 012009. 1-8

Asy'ary, M., Cahyono, B. 2006.PraStandarisasi: Produksi dan Analisis Minyak Virgin Coconut Oil (VCO). https://www.researchgate.net/public ation/273755055

Bekkum, H. V., Flanigen, E. M. , Jansen, J. C. 1991. Introduction to Zeolite Science and Practice.Netherland :Elsevier.

Dayrit, CS. 2000. Coconut Oil in Health and Disease: Its and Monolaurin's Potential as Cure for for HIV/AIDS. XXXVII Cocotech Meeting. Chennai, India. July 25

Hee, Y. Y., Tan, C. P., Rahman,R. A., Smith Jr, R. L, Chong, G. H. 2017.Production of Virgin Coconut Oil Microcapsules from Oil-In-Water Emulsion with Supercritical Carbon Dioxide Spray Drying. The Journal of Supercritical Fluids. 130. 118-124.

Ketaren, S. 1986. Pengantar Teknologi Minyak dan Lemak Pangan, Jakarta : Ul-Press.
Marina, A.M, Che Man, Y.B, Nazimah, S.A.H, Amin, I. 2009. Antioxidant Activity and Pheenolic Acids of Virgin Coconut Oil.J. Food Sciences and Nutrition.. 60: 114-123.

Nurani, I., Septyaningsih, D., Hardiyanti, I. S., Wibowo, EAP. 2016. Analisis Keefektifan Zeolit pada Proses Pemurnian Minyak Jelantah. Prosiding Seminar Nasional XI Rekayasa Teknologi Industri dan Informasi 2016 Sekolah Tinggi Teknologi Nasional Yogyakarta. 368-372.

Oseni, N. T., Fernando, W.M.A.D.B, Coorey, R., Gold, I., Jayasena, V. 2017. Effect of Extraction Techniques on the Quality of Coconut Oil. African Journal of Food Science 11 (3), 58-66

Sardi Hi.D., N. Alam, D. Sarro. 2017. Karakteristik Coconut Virgin Oil (VCO) yang Dipanen Pada Beberapa Ketinggian Tempat tumbuh. e- Journal 5 (4) : 431 - 440 